\title{
VISCERAL LEISHMANIASIS IN BRAZIL: REVISITING PARADIGMS OF EPIDEMIOLOGY AND CONTROL
}

\author{
Filipe DANTAS-TORRES(1,2) \& Sinval Pinto BRANDÃO-FILHO(1)
}

\begin{abstract}
SUMMARY
In the last 20 years, despite the known underestimation of cases, Brazil registered a marked increase in the incidence of visceral leishmaniasis. The main goal of this review is to reflect on some aspects of this zoonosis in Brazil and also to encourage the discussion in order to find more viable, effective and affordable strategies to be implemented by the Brazilian Leishmaniasis Control Program. The current situation of visceral leishmaniasis in Brazil might be seen as a paradox: the most important aspects of the disease are known, but so far the control of this disease has not yet been achieved. The current control strategies have not been able to prevent the geographical expansion, and even a rise in the incidence and lethality of visceral leishmaniasis. There is a need not only for a better definition of priority areas, but also for the implementation of a fieldwork monitoring system to the disease surveillance that could permit a further evaluation of the control program in areas where visceral leishmaniasis is endemic.
\end{abstract}

KEYWORDS: Visceral leishmaniasis; Epidemiology; Control; Paradigms; Brazil.

\section{INTRODUCTION}

Leishmaniases are diseases with significant clinical and epidemiological diversity, which involves many different species of Leishmania parasites, phlebotomine sandfly vectors, and reservoir hosts in both zoonotic and anthroponotic cycles of transmission. There is a remarkable increase in risk factors for leishmaniases worldwide and the disease burden is increasing ${ }^{22}$. Visceral leishmaniasis (VL) is the most devastating form of leishmaniases, because it is usually fatal if untreated. It is officially estimated that about 500,000 cases and 59,000 deaths occur every year due to this form of leishmaniases ${ }^{24,48,49}$. VL represents a serious problem of public health in both Old and New World. However, some $90 \%$ of cases occur in poor rural and suburban areas of Bangladesh, India, Nepal, Sudan and Brazil, the latter responsible for most of cases reported in Latin America ${ }^{34}$. About $80 \%$ of VL victims have less than US\$ 2 a day to live on ${ }^{49}$.

In developing countries of South America, the control of VL is clearly more complex than in Mediterranean countries. In developing countries there are a number of ecological, epidemiological, and socioeconomic factors that may reduce the impact of the control programs. In Brazil, for example, about 3,500 cases of VL are notified every year and, generally, they are associated with both poor living conditions and infant malnutrition ${ }^{9,40,42}$. On the other hand, in developed countries the situation is at least different. In Mediterranean countries (e.g. Spain), the culling of seropositive dogs and insecticide house spraying are not used as usual control measures ${ }^{21}$. Annually, thousands of people get infected with $L$. infantum (synonymous L. chagasi ${ }^{33}$ ) in these countries, but, unexpectedly, only a few of them get sick or die due to VL. Additionally, the cases are usually associated to other health conditions, such as HIV infection. How can these different patterns of the disease be explained? Obviously, the comparison between so different countries, like Brazil and Spain, is difficult, because many other aspects such as people's behaviors, level of education and socio-economic conditions must be considered.

For quite some time, the etiologic agent of VL, its molecular biology, and antimicrobial susceptibility have been studied. A number of advances have also been obtained on taxonomy, genetics, molecular biology and behavior of Lutzomyia longipalpis, the main vector of $L$. infantum in Brazil. The host immune response and its implications for diagnosis, treatment, and prevention of VL have also been investigated. Many aspects of the disease ecoepidemiology were discovered in the last 20 years, and this has been used for the development of new control measures. However, a marked increase in the incidence of VL was observed in the last two decades. From 1980 to 2003, a total of 51,222 cases were officially notified in Brazil ${ }^{11}$.

As observed with other communicable diseases (e.g. tuberculosis), the most important features of VL are well understood,

(1) Centro de Pesquisas Aggeu Magalhães/Fundação Oswaldo Cruz, Recife, Brazil.

(2) Bolsista de Mestrado do CNPq.

Correspondence to: Dr. Sinval Pinto Brandão Filho. CPqAM/Fiocruz, Campus UFPE. Av. Moraes Rego s/n, 50670-420 Recife, PE, Brasil. e-mail: sinval@cpqam.fiocruz.br 
but the current control strategies are not sufficient to control the disease. How this paradox can be explained? In this context, we reflect here on some aspects of VL in Brazil, aiming to contribute to the discussion in order to find more effective and feasible control measures to be implemented in the Brazilian Leishmaniasis Control Program (BLCP).

\section{The dog and other possible domestic source of infection}

In Brazil, the domestic dog Canis familiaris has long been incriminated as the main reservoir of L. infantum infection. It is because the high susceptibility to infection and high skin parasitism frequently observed in this host and mainly due to its close relationship with $\operatorname{man}^{6}$, in both rural and urban areas. Hence, the presence of seropositive dogs in human dwellings is seen as a possible risk factor for L. infantum infection ${ }^{17}$.

From 1980 to 1991, a total of 137,243 dogs (both seropositive and stray dogs) were killed during the activities undertaken by the $\mathrm{BLCP}^{29}$. In the same period, several outbreaks of VL occurred in both rural and urban areas. The disease has expanded its area of occurrence, and now it is endemic in at least 19 Brazilian states. In the same way, the incidence rate of VL continues to increase and the lethality is still around $10 \%$ 4,40,42. What is going on? Are domestic dogs the sole source of infection in all foci of VL in Brazil? Can asymptomatic infected people also be acting as reservoir hosts in urban areas? Can the culling of seropositive dogs reduce the incidence rate of VL in humans? Many plausible explanations could be providing on these questions but, in fact, this is a complex issue and the opinions may vary widely.

Indeed, domestic dogs are the main domestic reservoirs of $L$. infantum infection in the transmission cycle of zoonotic visceral leishmaniasis $(\mathrm{ZVL})^{16,20}$. But, can other domestic or synanthropic animals play any role as reservoirs of infection? Recently, a domestic cat Felis catus was found naturally infected with L. infantum in an area of transmission of VL in São Paulo State ${ }^{43}$. However, the epidemiological role of the cat is still unclear.

In 2002, the role of the domestic chicken Gallus gallus in the epidemiology of urban VL in Brazil was discussed ${ }^{1}$. There are some factors precluding the chicken as a Leishmania host, impeding this species as a reservoir ${ }^{51}$. It is known that Leishmania infection is unable to develop in some birds and also that existing infections in the phlebotomine sandfly might be eliminated when it ingests a second blood meal from chickens. On the other hand, chickens are very attractive to phlebotomine sandflies and also to reservoir hosts of L. infantum infection, such as the crab-eating fox Cerdocyon thous. Consequently, the chickens might favor the link between the sylvatic and domestic transmission cycles. Thus, in some regions, the domestic chickens must be seen as a risk factor for the presence of vectors and reservoir hosts of $L$. infantum next to human habitations.

L. infantum/HIV co-infection is a relatively new major challenge for public health in many countries ${ }^{2,36}$, including Brazil ${ }^{4}$. It has been proven that $L$. infantum/HIV co-infected patients might be highly infectious to phlebotomine sandflies ${ }^{35}$. In Spain, the incidence of coinfection is high, and some $68 \%$ of the L. infantum/HIV patients are intravenous-drug users. Hence, there has also been speculation of human-human transmission by means of shared needles ${ }^{2}$. Occasionally, Leishmania parasites may also be transmitted by blood transfusion ${ }^{31,39}$. It is usually believed that infected people are only incidental hosts of L. infantum infection, but there is evidence indicating that infected people might also act as reservoir of infection for phlebotomine sandflies. In fact, a recent study demonstrated that Brazilian subjects with active VL might act as source of L. infantum infection to colonized Lu. longipalpis ${ }^{15}$.

\section{Sylvatic reservoir hosts}

The crab-eating fox have been incriminated as the primary reservoir host of L. infantum infection in Brazil and Venezuela ${ }^{20,30}$. In general, the infection rates in canids other than the domestic dog is low, but sometimes might be high, as observed in South American foxes. However, wild canids do not live either near or in human habitation and, hence, they have a secondary importance in the epidemiology of ZVL.

The opossum Didelphis albiventris was found naturally infected by L. infantum in Brazil ${ }^{44,45}$, as well as D. marsupialis in Colombia ${ }^{13,47}$ and Venezuela ${ }^{52}$. In Barra de Guaratiba, Rio de Janeiro State, the distance of the house from the forest border, its altitude and the presence of $D$. marsupialis in the backyard were found to be predictor factors for L. infantum infection in $\operatorname{dogs}^{11}$. There are some records of natural infection in both domestic and wild rodents. In Italy, the common domestic rat Rattus rattus is strongly suspected as a secondary reservoir of $L$. infantum ${ }^{48}$ and there is a record of L. chagasi infection in this same rodent in Venezuela ${ }^{52}$. Records of natural infection were also verified in the spiny rat Proechimys canicollis in Colombia ${ }^{13}$. Using a PCR technique, we have recently detected the presence of $L$. infantum DNA fragment in an exemplar of water rat Nectomys squamipes and in an opossum D. albiventris, both trapped in an Atlantic rain forest area of Pernambuco State (unpublished data). These findings are evidences that other sylvatic mammals might be involved in the maintenance of the L. infantum enzootic cycle, acting as primary reservoir hosts of this parasite.

In fact, some non-domestic mammals (e.g., $R$. rattus and $D$. albiventris) that were already found naturally infected with $L$. infantum are considered to be synanthropic animals (i.e., non-domestic animals that habitually share and profit from the human ecotope). This process of domiciliation is important for the establishment of new epidemiological patterns of VL, particularly in the urban cycle of transmission.

\section{The Brazilian Leishmaniasis Control Program (BLCP)}

Although the BLCP has spent an important amount of initiatives to surveillance and control of VL, the current disease burden indicates that more and more efforts are still need. The World Health Organization (WHO) is working in the establishment of public-private partnerships to attract more resources for both research and control of leishmaniasis ${ }^{23}$, but most of the current research effort and resources should priorize areas where the disease burden is greatest ${ }^{19}$.

The BLCP is based on three main control measures: diagnosis and 
early treatment of human cases, immunological screening and culling of seropositive dogs and insecticide spraying against phlebotomine sandflies. These control strategies have remained unchanged since the 1950 ' $\mathrm{s}^{20}$, and have not been able to reduce the incidence of human cases to an acceptable level ${ }^{8,14}$. Indeed, the prevalence of VL has been increased and the disease has become a serious public health problem in several Brazilian states.

In the past few years, it has been suggested that there is a need for a closer approximation between researchers and public health workers in order to revise the current control strategies and to define procedures capable of accurately assessing their impact ${ }^{14,29}$. Many initiatives have been developed, including the implementation of reference services by the Health Surveillance Secretary of the Ministry of Health. Recently, the activities of the BLCP were decentralized and now they are under responsibility of the municipalities. However, after this decentralization, the performance of local teams should be monitored by the central level, which needs not only to evaluate, but also to support the developed activities. This is important for the improvement of the BLCP and thereby its impact would be better evaluated.

\section{Culling of seropositive dogs: a limited impact}

In the past, experts in the field of leishmaniasis ${ }^{6}$ recognized that there is no well-established control strategy for canine leishmaniasis and until now the efficacy of dog culling remains highly questionable ${ }^{23}$. The true number of dogs that need to be killed in order to decrease the incidence of VL in man is unknown. Moreover, the selective elimination of seropositive dogs is expensive and difficult to implement $t^{6,23}$, and it risks antagonizing people against the authorities responsible 6 .

There are several points to be considered on the culling of seropositive dogs: the limitation of the immunological screenings to detect anti-Leishmania antibodies, either with indirect immunofluorescence assay ${ }^{3}$ or enzyme-linked immunosorbent assay ${ }^{16}$, the opposition of dog owners to the culling of asymptomatic dogs, and the lack of evidence that this method is effective to reduce the incidence rate of VL in all areas where it has been used ${ }^{14}$. It has been demonstrated that the culling of seropositive dogs has a limited impact on the reduction of human incidence ${ }^{5,25,34}$. Mathematical models have also shown the limitations of this strategy ${ }^{16}$, which may be less effective than others ${ }^{26}$.

A recent study showed that dog-culling programs do not reduce the incidence of canine Leishmania infection ${ }^{40}$. From 1997 to 2000 a cohort of dogs in an urban area in Brazil was followed up and the authors observed that several dogs immigrated to the study area throughout the study period. These new dogs replaced most of the eliminated ones. Most important, it was the fact that $15 \%$ of the new dogs had already Leishmania infection. This study not only pointed down the effectiveness of dog-culling programs, but also showed that new strategies for VL control are need.

\section{Phlebotomine sandfly control}

The DDT was the first insecticide used against phlebotomine sandflies in Brazil. During the 1950's, the late "Departamento Nacional de Endemias Rurais (DENERu)" used this insecticide against these vectors in many foci of the disease ${ }^{20}$. Despite of the side effects on both human health and environment, the DDT is still used today ${ }^{34}$, though other insecticides have been used, such as pyrethroids (e.g. deltamethrin $)^{9,38}$.

Other alternatives have been proposed for the control of phlebotomine sandflies. Insecticide-impregnated dog collars, for example, can protect dogs from the bites of the vectors for several weeks ${ }^{18,27,32,41}$. The community-wide application of deltamethrinimpregnated dog collars had already showed efficacy not only to protect dogs from $L$. infantum infection, but also in reducing the risk of infection in Iranian children ${ }^{27}$. This is a good strategy that should be used in areas of high transmission, based on knowledge of vector's seasonality, and also in dogs from non-enzootic areas during trips to enzootic areas.

In general, it is said that the vector control is one of the most important measures in the control of vector-borne diseases. But there is a consensus that the control of phlebotomine sandflies is not an easy task. Their breeding sites, are difficult to find, which limits the development of control measures focused on immature forms of these vectors. In Brazil, it is known that Lu. longipalpis populations are widely spread in both rural and urban areas. However, there is a lack of field studies demonstrating the degree of endo/exophily and endo/ exophagy of Lu. longipalpis in several foci of the disease. Undoubtedly, before choosing the vector control strategy, it is important to further know these aspects of the phlebotomine sandfly behavior ${ }^{24}$.

\section{Canine vaccination: a current discussion}

An efficient antileishmanial vaccine for dogs would be an alternative to prevent leishmaniasis in dogs. Currently, there has been discussion on a new vaccine against canine visceral leishmaniasis (Leishmune Fort Dodge Animal Health) that was recently registered by the Brazilian Ministry of Agriculture, Livestock and Food Supply. However, this new possibility was the aim of much debate and was not recommended by the Ministry of Health ${ }^{11}$. This position has been justified by the lack of field studies showing the impact of dog vaccination on the incidence of VL in humans and the cost-effectiveness of this measure.

A multidisciplinary group of researchers have long been studying the FML-vaccine ${ }^{7,46}$. A field study in a LV-endemic area of Rio Grande do Norte State showed that this vaccine induced a significant long lasting and strong protective effect against canine visceral leishmaniasis ${ }^{7}$. These studies also demonstrated that almost all vaccinated dogs presented detectable antibodies against Leishmania antigens and, at the moment, there is no way to distinguish antibodies developed due to natural infection from those developed due to vaccination. Hence, since seropositive dogs are often eliminated during the activities of the BLCP, the vaccinated dogs could be erroneously eliminated. New tools capable of identifying antibodies produced specifically due to vaccination would be the best way to resolve this limitation.

Several aspects of the mechanisms of antileishmanial immune responses in canine infection have been clarified by recent studies, though many aspects remain to be discovered. Anyway, some advances 
on canine Leishmania vaccines have been achieved due to these recent findings. The antileishmanial vaccine candidates include live or killed parasites, Leishmania purified fractions, defined recombinant parasite antigens, live recombinant bacteria expressing Leishmania antigens and antigen-encoding DNA plasmids ${ }^{28}$.

\section{Conclusions and perspectives}

VL is a focal disease and local epidemiology might differ widely. Hence, the understanding of details of the reservoir system structure in each focus is a crucial step to adopt efficient control measures focused on the reservoirs of infection ${ }^{6}$. In the last few years, some improvements have been obtained on the understanding of the structure of these reservoir systems, but much remains to be discovered.

The restructuration of the diagnosis network should be the first step to improve the BLCP. The second one is a better basic health attention on the early treatment of human cases of VL in order to reduce the lethality of the disease. More resources will be also needed to study the behavior of phlebotomine sandfly populations, either in areas where VL is endemic or in those where only sporadic cases have been reported. Preventive measures directed to reduce the human-vector contact must be implemented based on the previous knowledge of vector behavior only. Likewise, the implementation of a fieldwork monitoring system is justified and would permit a further evaluation, of the measures recommended by the BLCP.

Both development and implementation of new control measures are priorities and should be supported by institutions of both public and private sectors. This is particularly true in the poorest communities at risk of VL, where the use of either insecticide-impregnated dog collars or a canine vaccine without financial support will be impracticable.

For decades, researchers have warned that the risk of VL is increasing in Brazil. In its reports, the Ministry of Health, showed the process of urbanization of VL. Consequently, we can say that the current situation has been predicted. Nowadays, the biggest challenge in control of infectious diseases, such as VL, is how to translate the knowledge derived from research into cost-effective, accessible, and affordable control measures. New approaches, such as rapid diagnostic tools and new affordable/effective therapeutic options are welcome ${ }^{50}$. In the same way, it is well known that to improve the quality of life of the population at risk is a good way to prevent many infectious and parasitic diseases, which are usually associated to deficient water supply, malnutrition and poor living conditions. The development of public policies in order to improve both individual and community health among the population at risk of $\mathrm{VL}$ is crucial and this perspective is particularly important in Brazil.

The topics discussed in this paper are important for a better knowledge of the VL epidemiology and should therefore be intended as a contribution to the BLCP improvement. VL in Brazil is a complex problem, but a problem that may have solution. How to solve it? Undoubtedly, to solve it will be possible if, and only if, researchers and fieldwork programs work together. After all these years of attempts without success, something has been learned: the solution for the paradoxical situation of VL in Brazil is seen as an issue of scientific development and permanent health surveillance, but it is also an issue of social justice and better quality of life for the population at risk.

\section{RESUMO}

\section{Leishmaniose visceral no Brasil: revisitando os paradigmas da epidemiologia e controle}

Nos últimos 20 anos, apesar da conhecida subestimação de casos, o Brasil registrou um marcado aumento na incidência da leishmaniose visceral. O principal objetivo desta revisão é refletir sobre alguns aspectos desta zoonose no Brasil e também encorajar a discussão a fim de encontrar novas estratégias, mais viáveis e efetivas, para serem implementadas no Programa Brasileiro de Controle das Leishmanioses. A situação atual da leishmaniose visceral no Brasil pode ser vista como um paradoxo: os aspectos mais importantes da doença são conhecidos, mas o controle desta doença ainda não foi conseguido. As estratégias de controle atuais não têm sido capazes de prevenir a expansão geográfica, além do aumento da incidência e da letalidade da leishmaniose visceral. Existe a necessidade de uma melhor definição das áreas prioritárias, mas também da implementação de um sistema de monitoramento das atividades dirigidas para o controle e vigilância epidemiológica, o que poderia permitir melhor avaliação do programa de controle nas diversas regiões do Brasil.

\section{ACKNOWLEDGMENT}

We thank the referees for their comments and suggestions. Thanks also to Sidney Pratt and Mércia Arruda for English revision and usefull comments.

\section{REFERENCES}

1. ALEXANDER, B.; DE CARVALHO, R.L.; McCALLUM, H. \& PEREIRA, M.H. - Role of the domestic chicken (Gallus gallus) in the epidemiology of urban visceral leishmaniasis in Brazil. Emerg. infect. Dis., 8: 1480-1485, 2002.

2. ALVAR, J.; CANAVATE, C.; GUTIERREZ-SOLAR, B. et al. - Leishmania and human immunodeficiency virus coinfection: the first 10 years. Clin. Microbiol. Rev., 10: 298-319, 1997.

3. ALVES, W.A. \& BEVILACQUA, P.D. - Quality of diagnosis of canine visceral leishmaniasis in epidemiological surveys: an epidemic in Belo Horizonte, Minas Gerais, Brazil, 1993-1997. Cadern. Saúde públ. (Rio de J.), 20: 259-265, 2004.

4. ALVES, W.A.; MAIA E., A.N.; OLIVEIRA, G.M. et al. - Leishmaniose visceral no Brasil: perfil dos casos no período de 2002 a 2004. Rev. Soc. bras. Med. trop., 38(supl. 1): 489, 2005.

5. ASHFORD, D.A.; DAVID, J.R.; FREIRE, M. et al. - Studies on control of visceral leishmaniasis: impact of dog control on canine and human visceral leishmaniasis in Jacobina, Bahia, Brazil. Amer. J. trop. Med. Hyg., 59: 53-57, 1998.

6. ASHFORD, R.W. - Leishmaniasis reservoirs and their significance in control. Clin. Derm., 14: 523-532, 1996.

7. BORJA-CABRERA, G.P.; CORREIA PONTES, N.N.; DA SILVA, V.O. et al. - Long lasting protection against canine kala-azar using the FML-QuilA saponin vaccine in an endemic area of Brazil (São Gonçalo do Amarante, RN). Vaccine, 20: 3277 3284, 2002.

8. BRAGA, M.D.M.; COELHO, I.C.B; POMPEU, M.M.L. et al. - Controle do calazar canino: comparação dos resultados de um programa de eliminação rápida de cães sororreagentes por ensaio imuno-enzimático com outro de eliminação tardia de cães sororreagentes por teste de imunofluorescência indireta de eluato de papel filtro. Rev. Soc. bras. Med. trop., 31: 419-424, 1998. 
9. BRASIL. MINISTÉRIO DA SAÚDE - Manual de vigilância e controle da leishmaniose visceral. Brasília, Ministério da Saúde, 2003.

10. BRASIL. MINISTÉRIO DA SAÚDE - Nota técnica sobre vacina anti-leishmaniose visceral canina. Accessed in: 30 December 2004. Available at: <http:// dtr2001.saude.gov.br>

11. BRASIL. MINISTÉRIO DA SAUUDE - Série histórica de casos e óbitos de doenças de notificação compulsória, Brasil, 1980 a 2003. Accessed in: 2 April 2005. Available at: <http://dtr2001.saude.gov.br>.

12. CABRERA, M.A.A.; PAULA, A.A.; CAMACHO, L.A.B. et al. - Canine visceral leishmaniasis in Barra de Guaratiba, Rio de Janeiro, Brazil: assessment of risk factors. Rev. Inst. Med. trop. S. Paulo, 45: 79-83, 2003.

13. CORREDOR, A.; GALLEGO, J.F.; TESH, R.B. et al. - Didelphis marsupialis, an apparent wild reservoir of Leishmania donovani chagasi in Colombia, South America. Trans. roy. Soc. trop. Med. Hyg., 83: 195, 1989.

14. COSTA, C.H.N. \& VIEIRA, J.B.F. - Mudanças no controle da leishmaniose visceral no Brasil. Rev. Soc. bras. Med. trop., 34: 223-228, 2001.

15. COSTA, C.H.N.; STEWART, J.M.; GOMES, R.B. et al. - Asymptomatic human carriers of Leishmania chagasi. Amer. J. trop. Med. Hyg., 66: 334-337, 2002.

16. COURTENAY, O.; QUINNELL, R.J.; GARCEZ, L.M.; SHAW, J.J. \& DYE, C. Infectiousness in a cohort of Brazilian dogs: why culling fails to control visceral leishmaniasis in areas of high transmission. J. infect. Dis., 186: 1314-1320, 2002.

17. CUNHA, S.; FREIRE, M.; EULALIO C. et al. - Visceral leishmaniasis in a new ecological niche near a major metropolitan area of Brazil. Trans. roy. Soc. trop. Med. Hyg., 89: 155-158, 1995.

18. DAVID, J.R.; STAMM, L.M.; BEZERRA, H.S. et al. - Deltamethrin-impregnated dog collars have a potent anti-feeding and insecticidal effect on Lutzomyia longipalpis and Lutzomyia migonei. Mem. Inst. Oswaldo Cruz, 96: 839-847, 2001.

19. DAVIES, C.R.; KAYE, P.; CROFT, S.L. \& SUNDAR, S. - Leishmaniasis: new approaches to disease control. Brit. med. J., 326: 377-382, 2003.

20. DEANE, L.M. - Leishmaniose visceral no Brasil: estudos sobre reservatórios e transmissores realizados no Estado do Ceará. Rio de Janeiro, Serviço Nacional de Educação Sanitária, 1956.

21. DESJEUX, P. - Information on the epidemiology and control of the leishmaniasis by country or territory. Geneva, World Health Organization, 1991.

22. DESJEUX, P. - The increase in risk factors for leishmaniasis worldwide. Trans. roy. Soc. trop. Med. Hyg., 95: 239-243, 2001.

23. DESJEUX, P. - Leishmaniasis. Nature Rev. Microbiol., 2: 692-693, 2004.

24. DESJEUX, P. - Leishmaniasis: current situation and new perspectives. Comp. Immunol. Microbiol. infect. Dis., 27: 305-318, 2004.

25. DIETZE, R.; BARROS, G.B.; TEIXEIRA, L. et al. - Effect of eliminating seropositive canines on the transmission of visceral leishmaniasis in Brazil. Clin. infect. Dis., 25: 1240-1242, 1997.

26. DYE, C. - The logic of visceral leishmaniasis control. Amer. J. trop. Med. Hyg., 55: 125-130, 1996.

27. GAVGANI, A.S.; HODJATI, M.H.; MOHITE, H. \& DAVIES, C.R. - Effect of insecticideimpregnated dog collars on incidence of zoonotic visceral leishmaniasis in Iranian children: a matched-cluster randomised trial. Lancet, 360: 374-379, 2002.

28. GRADONI, L. - An update on antileishmanial vaccine candidates and prospects for a canine Leishmania vaccine. Vet. Parasit., 100: 87-103, 2001.
29. LACERDA, M.M. - The Brazilian Leishmaniasis Control Program. Mem. Inst. Oswaldo Cruz, 89: 489-495, 1994.

30. LAINSON, R.; SHAW, J.J.; SILVEIRA, F.T. \& BRAGA, R.R. - American visceral leishmaniasis: on the origin of Leishmania (Leishmania) chagasi. Trans. roy. Soc. trop. Med. Hyg., 81: 517, 1987.

31. LUZ, K.G.; DA SILVA, V.O.; GOMES, E.M. et al. - Prevalence of anti-Leishmania donovani antibody among Brazilian blood donors and multiply transfused hemodialysis patients. Amer. J. trop. Med. Hyg., 57: 168-171, 1997.

32. MAROLI, M.; MIZZON, V.; SIRAGUSA, C.; D'OORAZI, A. \& GRADONI, L. Evidence for an impact on the incidence of canine leishmaniasis by the mass use of deltamethrin-impregnated dog collars in southern Italy. Med. vet. Ent., 15: 358363, 2001.

33. MAURICIO, I.L.; STOTHARD, J.R. \& MILES, M.A. - The strange case of Leishmania chagasi. Parasit. today, 16: 188-189, 2000

34. MILES, M.A.; VEXENAT, J.A.; FURTADO CAMPOS, J.H. \& FONSECA DE CASTRO, J.A. - Canine leishmaniasis in Latin America: control strategies for visceral leishmaniasis. In: PROCEEDINGS OF THE INTERNATIONAL CANINE LEISHMANIASIS FORUM, Barcelona, 1999. Wiesbaden, Hoechst Roussel Vet, 1999. p. 46-53.

35. MOLINA, R.; LOHSE, J.M.; PULIDO, F. et al. - Infection of sand flies by humans coinfected with Leishmania infantum and human immunodeficiency virus. Amer. J. trop. Med. Hyg., 60: 51-53, 1999.

36. MOLINA, R.; GRADONI, L. \& ALVAR, J. - HIV and the transmission of Leishmania Ann. trop. Med. Parasit., 97(suppl. 1): 29-45, 2003.

37. MOREIRA Jr., E.D.; MENDES DE SOUZA, V.M.; SREENIVASAN, M. et al. Assessment of an optimized dog-culling program in the dynamics of canine Leishmania transmission. Vet. Parasit., 122: 245-252, 2004.

38. OLIVEIRA-FILHO, A.M. \& MELO, M.T. - Vectors control importance on leishmaniasis transmission. Mem. Inst. Oswaldo Cruz, 89: 451-460, 1994

39. OTERO, A.C.; DA SILVA, V.O.; LUZ, K.G. et al. - Short report: occurrence of Leishmania donovani DNA in donated blood from seroreactive Brazilian blood donors. Amer. J. trop. Med. Hyg., 62: 128-131, 2000.

40. QUEIROZ, M.J.; ALVES, J.G. \& CORREIA, J.B. - Visceral leishmaniasis: clinical and epidemiological features of children in an endemic area. J. Pediat. (Rio de J.), 80: 141-146, 2004

41. REITHINGER, R.; COLEMAN, P.G.; ALEXANDER, B. et al. - Are insecticideimpregnated dog collars a feasible alternative to dog culling as a strategy for controlling canine visceral leishmaniasis in Brazil? Int. J. Parasit., 34: 55-62, 2004.

42. REY, L.C.; MARTINS, C.V.; RIBEIRO, H.B. \& LIMA, A.A. - American visceral leishmaniasis (kala-azar) in hospitalized children from an endemic area. J. Pediat. (Rio de J.)., 81: 73-78, 2005.

43. SAVANI, E.S.; de OLIVEIRA CAMARGO, M.C.; CARVALHO, M.R. et al. - The first record in the Americas of an autochthonous case of Leishmania (Leishmania) infantum chagasi in a domestic cat (Felix catus) from Cotia County, São Paulo State, Brazil. Vet. Parasit., 120: 229-233, 2004.

44. SHERLOCK, I.A.; MIRANDA, J.C.; SADIGURSKY, M. \& GRIMALDI JUNIOR, G. Natural infection of the opossum Didelphis albiventris (Marsupialia: Didelphidae) with Leishmania donovani in Brazil. Mem. Inst. Oswaldo Cruz, 79: 511, 1984

45. SHERLOCK, I.A. - Ecological interactions of visceral leishmaniasis in the state of Bahia, Brazil. Mem. Inst. Oswaldo Cruz, 91: 671-683, 1996.

46. SILVA, V.O.; BORJA-CABRERA, G.P.; CORREIA PONTES, N.N. et al. - A phase III trial of efficacy of the FML-vaccine against canine kala-azar in an endemic area of Brazil (São Gonçalo do Amaranto, RN). Vaccine, 19: 1082-1092, 2000. 
47. TRAVI, B.L.; JARAMILlO, C.; MONTOYA, J. et al. - Didelphis marsupialis, an important reservoir of Trypanosoma cruzi and Leishmania (Leishmania) chagasi in Colombia. Amer. J. trop. Med. Hyg., 50: 557-565, 1994.

48. WORLD HEALTH ORGANIZATION - Control of leishmaniasis: report of a WHO Expert Committee. Wld Hlth Org. techn. Rep. Ser., (793), 1990.

49. WORLD HEALTH ORGANIZATION - New treatment for leishmaniasis is $95 \%$ effective. Bull. Wld Hlth Org., 80: 688, 2002.

50. WORLD HEALTH ORGANIZATION - Report of the scientific working group on leishmaniasis. Geneva, WHO/TDR/SWG, 2004.
51. ZILBERSTEIN, D. \& SHAPIRA, M. - The role of $\mathrm{pH}$ and temperature in the development of Leishmania parasites. Ann. Rev. Microbiol., 48: 449-470, 1994.

52. ZULUETA, A.M.; VILLARROEL, E.; RODRIGUEZ, N. et al. - Epidemiologic aspects of American visceral leishmaniasis in an endemic focus in Eastern Venezuela. Amer. J. trop. Med. Hyg., 61: 945-950, 1999.

Received: 20 June 2005

Accepted: 7 March 2006 